J. Amer. Soc. Hort. Sci. 116(5):846-850. 1991.

\title{
NAA-induced Ethylene and ACC in 'Delicious' Spur Tissues: Changes with Temperature and Time
}

\author{
Eric A. Currv \\ U.S. Department of Agriculture, Agricultural Research Service, Tree Fruit Research Laboratory, \\ 1104 N. Western Avenue, Wenatchee, WA 98801 \\ Additional index words. Malus domestics, biennial bearing, fruit set, fruit drop, abscission auxin, plant growth \\ regulators, sensitivity

\begin{abstract}
These studies with apple (Malus domestica Borkh.) spur tissues were conducted to investigate the mechanism whereby NAA may stimulate fruit abscission in the spring but acts to prevent fruit drop in the fall. NAAinduced ethylene evolution from 'Delicious' spurs in vivo was similar to that evolved from excised leaf and fruit tissues that later were treated in the laboratory and incubated in darkness at $20 \mathrm{C}$. The peak in ethylene production occurred 24 hours after treatment at $30 \mathrm{C}, 48$ hours after treatment at $20 \mathrm{C}$, and production was still increasing 72 hours after treatment at 10C. Leaf tissue showed the greatest induction of ethylene from NAA followed by fruit and petiolar tissues. Induction was greatest early in the season and declined steadily until about "June drop." After this time, none of the tissues showed significant capacity for ethylene induction. Chemical names used: 2-(1 -naphthyl) acetic acid (NAA).
\end{abstract}

NAA is widely used in commercial apple production to induce abscission in the early development of the fruitlet (Burkholder and McCown, 1941), thereby reducing biennial bearing and regulating cropping. Crowe (1965) reported naphthalene acetamide reduced auxin-like substances in the exudates of fruit 1 day after treatment. Weinbaum and Simons (1974) and Schneider (1975a) found reduced transport of exogenously applied labelled sucrose to developing fruitlets within 2 days of NAA treatment. Schneider (1975b) also found increased ethylene evolution from excised fruit, leaves, and petioles $24 \mathrm{~h}$ after treatment with NAA.

In addition to inducing abscission in the spring, NAA is also used to prevent premature abscission of the fruit during the final maturation period before commercial harvest (Gardner et al., 1939). The purpose of this study was to examine the nature of this paradoxical effect by quantifying NAA-induced ethylene and 1-aminoeyclopropane-l-carboxylic acid (ACC) production of different apple spur tissues from petal fall through harvest.

\section{Materials and Methods}

The following experiments were conducted on similar trees in the same commercial orchard in Leavenworth, Wash., in $1987-88$.

Time course of NAA-treated spurs in situ. On 10 May 1987, at the full bloom stage, six 10-year-old, spur-type 'Delicious'/ seedling trees of similar blossom density and tree vigor were selected. On 24 May, at $\approx 0600 \mathrm{HR} ¥ 0$ days after petal fall, 10 spurs on each tree, each supporting two viable fruitlets, were tagged and treated with $10 \mathrm{mg}$ NAA/liter plus $1000 \mathrm{mg}$ nonionic surfactant/liter (Regulaid, Kalo Laboratories, Kansas City, Me.). An additional 10 spurs on each tree were treated with $1000 \mathrm{mg}$ Regulaid/liter to serve as controls. After allowing the spur tissues to air dry for 30 rein, a no. 6 rubber sleeve stopper with a 4-mm hole and a longitudinal cut through one side was fitted around the base of the bourse, and a 125-ml Erlenmeyer flask

Received for publication 10 Aug. 1990. The cost of publishing this paper was defrayed in part by the payment of page charges. Under postal regulations, this paper therefore must be hereby marked advertisement solely to indicate this fact. covered with aluminum foil was carefully placed over each spur and firmly pressed onto the rubber stopper. This sealed unit was left in place for $3 \mathrm{~h}$, after which time a $38-\mathrm{mm} 23 \mathrm{G}$ syringe needle was pushed through the rubber stopper and a 1-ml gas sample taken for a laboratory analysis of ethylene. The flasks were then removed. Again at 24, 48, 96, and $144 \mathrm{~h}$ after treatment, at $\approx 0600 \mathrm{HR}$, the procedure was repeated and a gas sample taken for analysis of ethylene. At the conclusion of the experiment, the spurs were excised and weighed. Ethylene was also sampled from a blank consisting of an empty Erlenmeyer flask with a solid rubber sleeve stopper that was placed in each tree. The amount of ethylene contained in the empty flask was subtracted from each individual flask to obtain a corrected value. Ethylene was quantified with a Hewlett-Packard 5880A gas chromatography equipped with an FID, a $30 \mathrm{~m} \times 0.53 \mathrm{~mm}$ i.d. GS-Q megabore column (J \& W Scientific, Folsom, Calif.), and a peak integrator.

Temperature response of spur tissues treated with NAA in the field. On 10 May $1988, \approx 3$ days after full bloom, five whole 12-year-old spur-type 'Delicious' trees were sprayed to drip with $10 \mathrm{mg}$ NAA/liter plus $1000 \mathrm{mg}$ Regulaid/liter. Five additional trees were also sprayed with $1000 \mathrm{mg}$ Regulaid/liter. After drying for 30 rein, three spurs from each tree were excised, placed in a styrofoam cooler at $4 \mathrm{C}$, and transported to the laboratory. The spurs from each five similarly treated trees were subdivided into three groups containing one spur from each tree. Each spur was then dissected into three tissue types: the leaf blade, the fruit, and the petiolar cluster. The tissues from each spur were weighed, placed in separate vials, and sealed with parafilm. One group from each treatment was placed in a dark incubator at either 10, 20 , or $30 \mathrm{C}$. After $3 \mathrm{~h}$, the gas in each vial was sampled with a syringe, and ethylene was quantified as previously described. At 24 and $48 \mathrm{~h}$ after treatment, spurs were also removed from the trees and treated identically to those taken immediately after treatment.

Temperature response of spur tissues treated with NAA in the laboratory. On 16 May 1988 at about petal fall, 18 spurs from each of five trees were removed from 12-year-old spur-type 'Delicious' trees and placed in styrofoam coolers at 4C for transport to the laboratory. The spurs were then divided into 18 groups containing one spur from each tree. Nine groups were 
treated by dipping the leaves and fruit in an aqueous solution containing $10 \mathrm{mg}$ NAA/liter plus $1000 \mathrm{mg}$ Regulaid/liter. The other nine groups served as controls and were treated with 1000 $\mathrm{mg}$ Regulaid/liter only. After drying for 30 rein, the bourse base was freshly cut and the end pushed through a hole in a styrofoam tray floating in distilled water. Three groups from each treatment were placed in dark incubators at 10,20 , or 30C. At 0 , 24 , and $48 \mathrm{~h}$ after treatment, one group of five spurs from each treatment was removed. Each spur was then dissected into three tissue types: the leaf blade, the fruit, and the petiolar cluster. The tissues from each spur were weighed, placed in separate vials, sealed with parafilm, and returned to the appropriate incubator. After $3 \mathrm{~h}$, the gas from each vial was sampled with a syringe and the ethylene measured as previously described.

Seasonal change in NAA-induced ethylene and ACC. Beginning on 25 May 1988, at 10 days after petal fall and every 2 to 4 weeks thereafter, nine whole spurs with one or two fruitlets were excised from each of six 11-year-old 'Delicious' trees and placed in a styrofoam cooler chest kept at $\approx 4 \mathrm{C}$ for transport to the laboratory. The intact spur leaves, fruit, and pedicel were then dipped in 0,10 , or $50 \mathrm{mg}$ NAA/liter plus $1000 \mathrm{mg}$ surfactant/liter and allowed to air dry for 30 rein, after which the bourse end was freshly cut and placed in deionized water. The spurs were placed in darkness at $20 \mathrm{C}$ for subsequent sampling of ethylene and ACC analysis. At 0,24 , and $48 \mathrm{~h}$ after treatment, a spur was dissected into three tissue types-the leaf blade, the fruit, and the petiolar cluster (leaf petiole and fruit pedicels). The tissues from each spur were weighed, placed in separate vials, sealed, and placed in darkness at 20C. After 3 $\mathrm{h}$, the gas from each vial was sampled with a syringe, and the tissue immediately frozen in liquid nitrogen and stored at $-80 \mathrm{C}$ for further analysis. ACC was quantified according to published techniques (Lizada and Yang, 1979); using the method of standard addition to account for seasonal variations in efficiency of conversion of ACC to ethylene. For this method, three identical samples from each tissue type were spiked with 0,10 , or $20 \mathrm{ng}$ ACC. A least-squares linear regression was calculated for each tissue series and the slope used to determine the conversion efficiency of ACC to ethylene and, thus, the amount of ACC in the unspiked sample.

In the preceding three experiments, empty vials sealed with parafilm were treated as blanks, and any residual amount of ethylene was subtracted from the corresponding sample.

\section{Results and Discussion}

Time course of NAA-treated spurs in vivo. Whole spurs treated with NAA at $10 \mathrm{mg}$ and sampled for ethylene in vivo showed an ethylene peak at $\approx 48 \mathrm{~h}$ following treatment (Fig. 1). Even after $144 \mathrm{~h}$, the production of ethylene remained significantly higher than in the controls. It appears that ethylene from control spurs was beginning to increase as well, but whether this rise was due to increasing ambient temperatures, a change in the particular stage of tissue development, or stress from repeated handling is unknown. Weather during the 6-day experiment was dry and air temperatures during the sampling period were in the range 15-20C.

Results of this trial are similar to those of Schneider (1975b) who found an increase in ethylene evolution from excised spur tissues from 'Red Rome', 'Golden Delicious', and 'Staymared' trees 15 days after petal fall. Schneider reported a peak $48 \mathrm{~h}$ after spraying the entire spurs in the field. Walsh et al. (1979) also reported an increase in ethylene evolution from excised

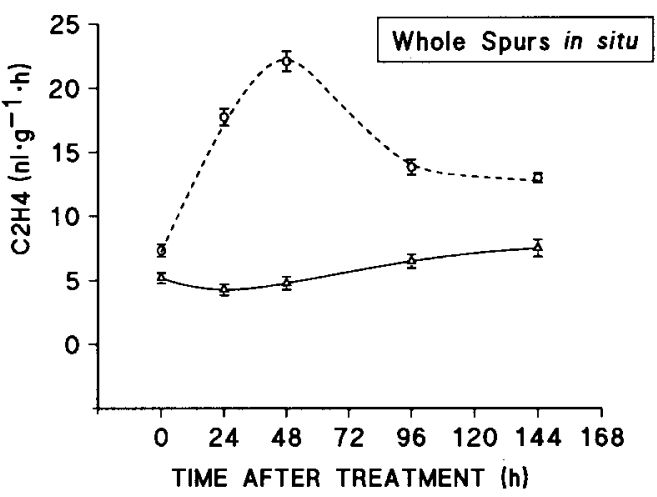

Fig. 1. Ethylene evolution from whole apple spur tissues in situ treated with $10 \mathrm{mg}$ NAA/liter plus $1000 \mathrm{mg}$ nonionic surfactant (Regulaid)/ liter (---) or only with $1000 \mathrm{mg}$ Regulaid/liter (sampled at 0600 HR 24, 48,96, and $144 \mathrm{~h}$ after treatment. Vertical bars indicate $\pm \mathrm{SE}$.

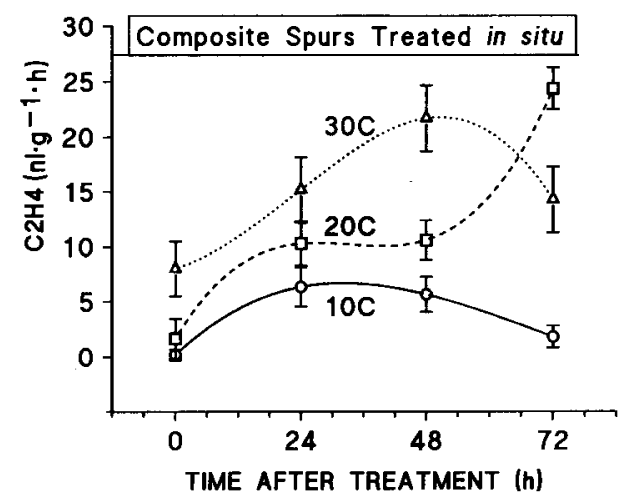

Fig. 2. Ethylene evolution from composite samples consisting of excised fruit, petiolar, and leaf tissues treated in situ with $10 \mathrm{mg} \mathrm{NAA} /$ liter plus $1000 \mathrm{mg}$ Regulaid/liter and incubated for $3 \mathrm{~h}$ in darkness at $10 \mathrm{C}(-), 20 \mathrm{C}(-\cdots)$, or $30 \mathrm{C}(\cdots)$. Spurs were treated 10 May 1988, 3 days after full bloom, and sampled at 0, 24, 48, and $72 \mathrm{~h}$ after treatment. Vertical bars indicate \pm SE.

'Golden Delicious' spurs treated with $15 \mathrm{mg}$ NAA/liter at petal fall.

Temperature response of spur tissues treated with NAA in the field. Ethylene production rates from the various spur parts were combined to show composite rates generated by each spur at each incubation temperature (Fig. 2). At $48 \mathrm{~h}$ after treatment, spurs kept at 30C showed a peak in ethylene production more than twice that of composite samples kept at either 10 or $20 \mathrm{C}$. The main contribution of each composite sampling was provided by the leaf tissue. Petiolar tissue showed the least amount of ethylene production, reaching a maximum of $1.5 \mathrm{nl} \cdot \mathrm{g}^{-1} \cdot \mathrm{h}^{-1}$ which produced no more than $4 \mathrm{nl} \cdot \mathrm{g}^{-1} \cdot \mathrm{h}^{-1}$ at any time during the study. Leaf tissue, however, generated $>25 \mathrm{nl} \cdot \mathrm{g}^{-1} \cdot \mathrm{h}^{-1} 48$ $\mathrm{h}$ after treatment when incubated at 30C. All spurs in the study were subjected to the same variations in ambient temperature ranging from $\approx 24 \mathrm{C}$ in the day to $\approx 10 \mathrm{C}$ at night over the $72 \mathrm{~h}$. It appeared from this experiment that although ACC may have been accumulating within the tissue, the capacity to metabolize it further to ethylene was the limiting factor. Incubating the tissues at a higher temperature allowed the ethylene to be produced more quickly. At $48 \mathrm{~h}$ after treatment, the $\mathrm{Q}_{10}$ for this conversion was $\approx 2$.

Temperature response of spur tissues treated with NAA in the laboratory. When whole spurs were removed and treated in the 
laboratory with NAA at $10 \mathrm{mg} \cdot \mathrm{liter}^{-1}$, the temperature at which the tissue was kept had a significant impact on the amount of ethylene evolved and the time at which the peak in ethylene production occurred. As in the previous experiment, composite ethylene production rates are presented (Fig. 3). At 20C, the peak in ethylene production occurred at $48 \mathrm{~h}$, simulating most closely NAA-induced ethylene in vivo. At 10C, the rise in ethylene began $24 \mathrm{~h}$ after treatment and continued slowly until the end of the experiment at $72 \mathrm{~h}$, never reaching a peak. Tissues incubated at 30C produced a peak slightly higher and $24 \mathrm{~h}$ earlier than that produced at $20 \mathrm{C}$.

Leaf tissue treated with NAA showed the highest rate of ethylene production of the three tissue types as in the previous experiment (data not shown). In contrast, fruit tissue showed the least amount of ethylene production during the experiment, reaching a maximum of $9 \mathrm{nl} \cdot \mathrm{g}^{-1} \cdot \mathrm{h}^{-1}$, followed by the petiolar tissue whose greatest rate of production wa $\approx 20 \mathrm{nl} \cdot \mathrm{g}-\mathrm{l} \cdot \mathrm{h}-1$. Leaf tissue produced the most ethylene, generating $>60$ $\mathrm{nl} \cdot \mathrm{g}^{-1} \cdot \mathrm{h}^{-1} 24 \mathrm{~h}$ after treatment at 30C. In addition, leaf tissue exhibited behavior more closely resembling that of typical enzyme kinetics than the other tissues, i.e., ethylene production increased with temperature. As in the previous experiment, although at $24 \mathrm{~h}$ instead of $48 \mathrm{~h}$, the $\mathrm{Q}_{\text {Iо }}$ was $\approx 2$.

Seasonal change in NAA-induced ethylene and ACC. Results of the previous experiment suggested excised spurs treated with NAA in the laboratory and kept at $20 \mathrm{C}$ would serve as a suitable system for studying the seasonal change in NAA-induced ethylene. In quantifying the amounts of ethylene and ACC at 0 , 24 , and $48 \mathrm{~h}$ after treatment, in practically every case, the amount of ethylene $48 \mathrm{~h}$ after treatment was greater than that at either 24 or $72 \mathrm{~h}$ (data not shown). Thus, for clarity, and to make differences among tissues most obvious, data are shown only for analyses at $48 \mathrm{~h}$ after treatment.

In this study, fruit treated only with $1000 \mathrm{mg}$ Regulaid/liter showed high rates of ethylene production early in development. Thereafter, rates continually declined. Treatment with either 10 or $50 \mathrm{mg}$ NAA/liter stimulated fruitlet ethylene production slightly at the first sampling date; however, sample variability was high. Fruit tissue showed little response thereafter (Fig. 4a). Several workers have shown that ethylene evolves during the early development of the fruitlet and declines quickly during the 8 weeks after petal fall (Blanpied, 1972; Ebert and Bangerth, 1985; Walsh and Solomos, 1987). Regulaid also has been shown to induce

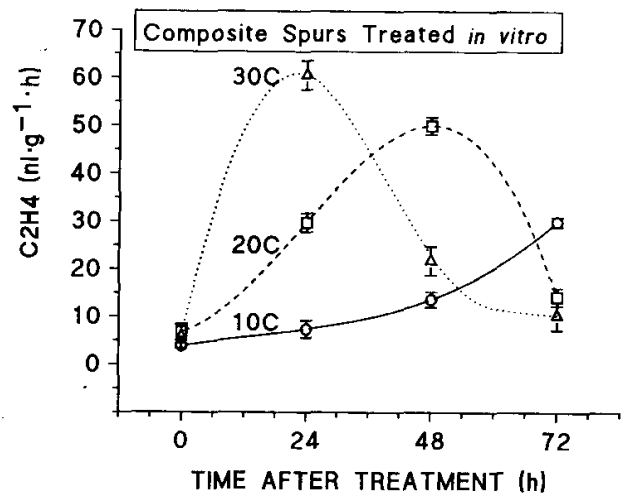

Fig. 3. Ethylene evolution from composite samples consisting of excised fruit, petiolar, and leaf tissues treated in vitro with $10 \mathrm{mg}$ NAA/liter plus $1000 \mathrm{mg}$ Regulaid/liter and incubated in darkness at $10 \mathrm{C}(-), 20 \mathrm{C}(-\cdots)$, or $30 \mathrm{C}(\cdots)$ for $0,24,48$, and $72 \mathrm{~h}$. Tissue was treated 16 May 1988 at petal fall. Vertical bars indicate \pm SE.
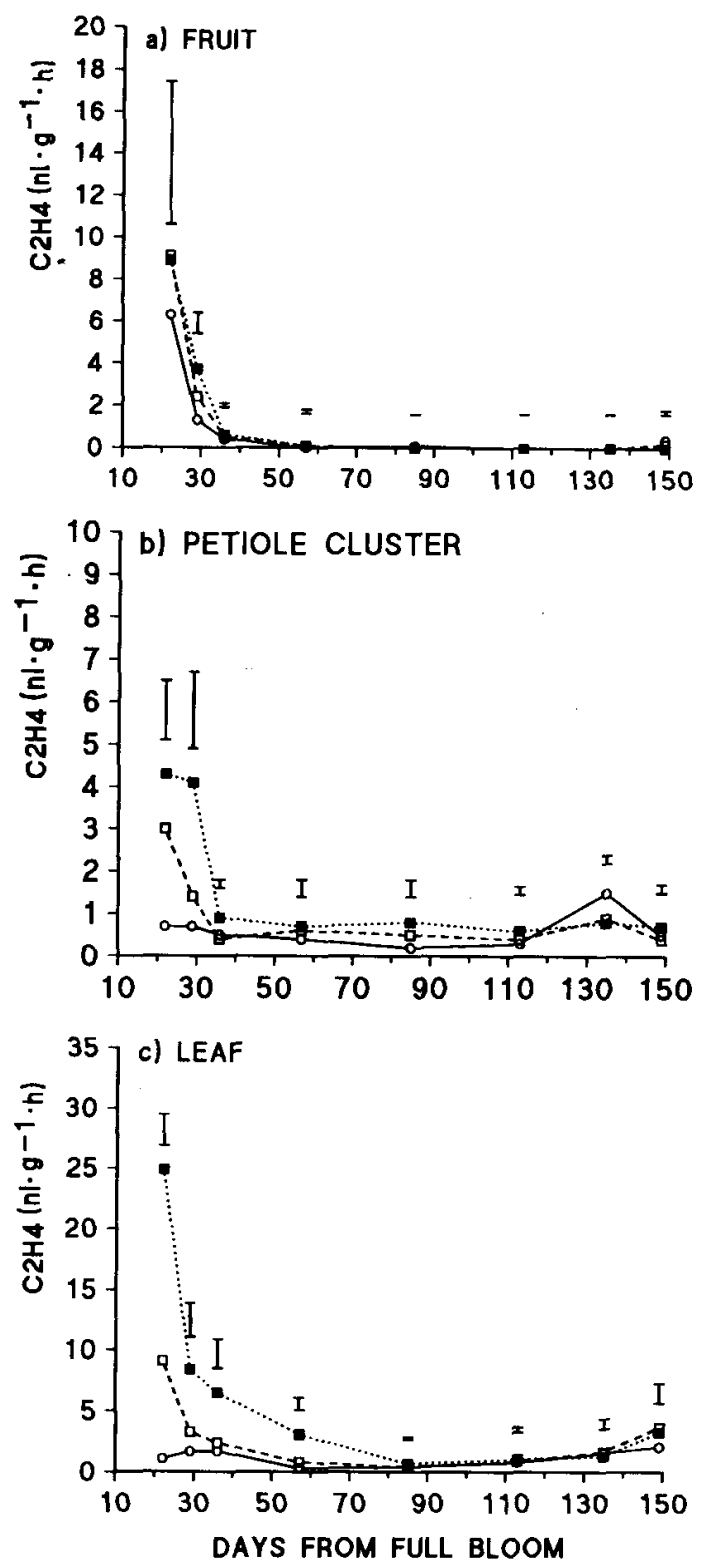

Fig. 4. Ethylene evolution from excised (a) fruit; (b) petiolar; and (c) leaf tissue treated in vitro with NAA at $0(-), 10(-\ldots)$, or $50 \mathrm{mg} \cdot \operatorname{liter}^{-1}(\cdots)$ plus $1000 \mathrm{mg}$ Regulaid/liter and incubated in darkness at $20 \mathrm{C}$ for $48 \mathrm{~h}$. Tissue was sampled beginning on 25 May 1988 and at intervals of 2 to 4 weeks. Vertical bars indicate $\pm \mathrm{SE}$.

ethylene production in young apple leaf tissue (Lownds and Bukovac, 1989); however, the effect appeared to be shorterlived than that induced by NAA.

Untreated petiole clusters produced little ethylene throughout the entire season (Fig. 4b). Treatment with either 10 or $50 \mathrm{mg}$ NAA/liter, however, significantly increased ethylene evolution, especially during the first four sampling periods. Little stimulation occurred thereafter.

Leaf tissue treated only with $1000 \mathrm{mg}$ Regulaid/liter maintained a somewhat higher basal level throughout the season than other tissues (Fig. 4c). Leaves treated with $10 \mathrm{mg} \cdot$ liter $^{-1}$ showed significant stimulation during the first 30 days after full bloom, whereas tissue treated with $50 \mathrm{mg} \cdot \mathrm{liter}^{-1}$ showed the highest rates of ethylene production of all treatments through 56 days after full bloom. After $\approx 85$ days after full bloom, no treatment effect was observed in any of the tissues (Fig. 4). 
Analysis of the frozen fruit tissue showed that the ACC concentrations were highest at the first sampling date and decreased (Fig. 5a) thereafter with a pattern similar to that of fruit ethylene production. There was no appreciable stimulation in response to NAA at either the 10 or $50 \mathrm{mg} \cdot$ liter $^{-1}$ dosage.

Petiolar tissue treated with Regulaid alone maintained levels of ACC considerably higher than similarly treated fruit tissue (Fig. 5b). NAA-stimulated levels were highest early in the season and generally declined thereafter. ACC levels in the petiole clusters showed the greatest variability of all tissues analyzed.

NAA-treated leaves at 10 or $50 \mathrm{mg} \cdot$ liter $^{-1}$ showed greatly increased concentrations of ACC, especially during the first three sampling dates for the former and four dates for $50 \mathrm{mg} \cdot \mathrm{liter}^{-1}$ (Fig. 5c). However, untreated leaves contained little ACC until the last two sampling dates when the concentration increased slightly. At 138 days after full bloom, NAA stimulated neither ethylene nor ACC production.
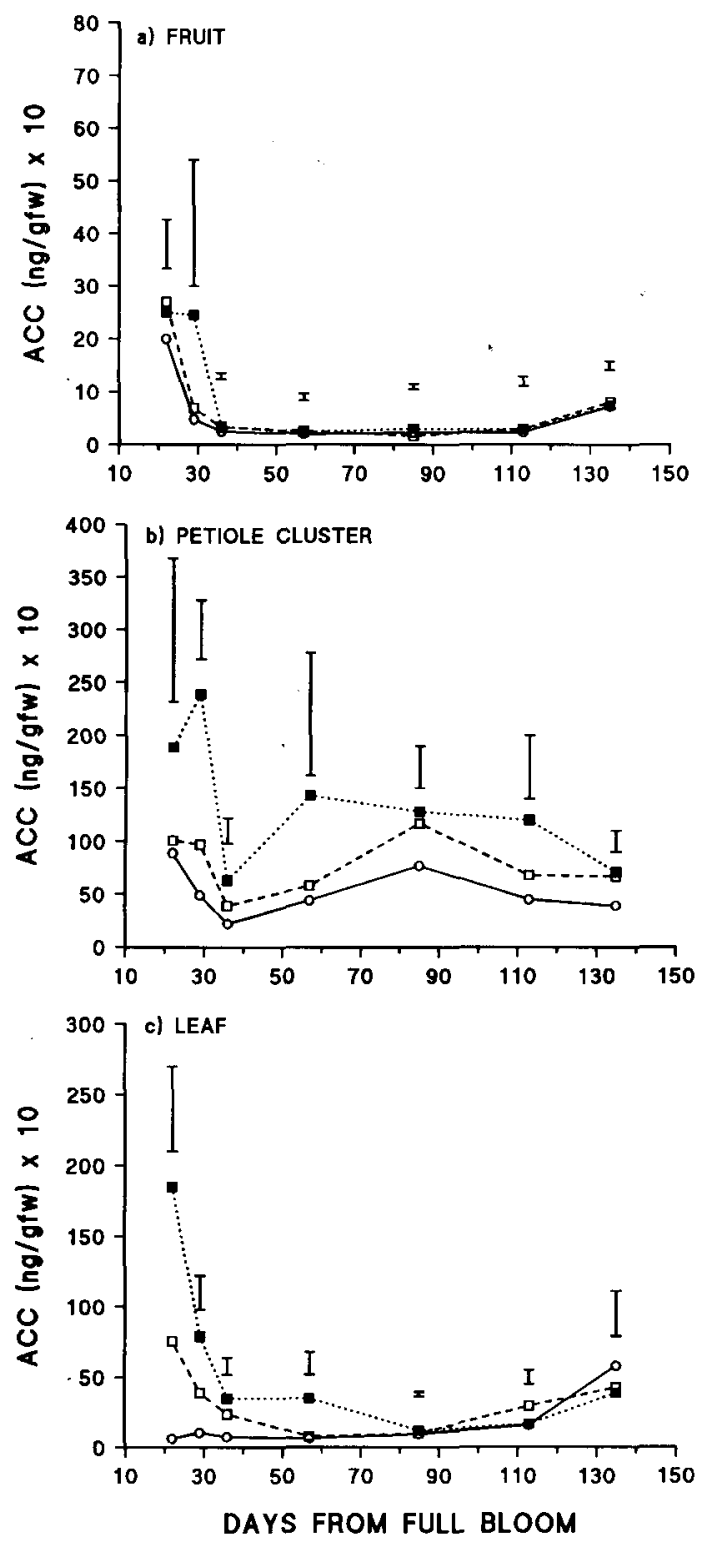

Fig. 5. ACC production from excised (a) fruit; (b) petiolar; and (c) leaf tissue treated in vitro with NAA at $0(-), 10(---)$, or $50 \mathrm{mg}(\cdots)$ plus $1000 \mathrm{mg}$ Regulaid/liter and incubated in darkness at $20 \mathrm{C}$ for $48 \mathrm{~h}$. Tissue was sampled beginning on 25 May 1988. Vertical bars indicate $\pm \mathrm{SE}$.
The method of standard addition for ACC analysis compensates for the change in conversion efficiency on a particular sampling date due to inhibiting compounds within the tissue. As the slope of the linear regression for each sample decreases, the efficiency of conversion of ACC to ethylene also decreases. Therefore, the mean of the slopes of the linear regression for each of the six samples that received no NAA was plotted against time for each tissue type. The linear regression of these values indicated that tissues generally lost conversion efficiency as the season progressed (Fig. 6). Leaf tissue showed the most consistent pattern of decreasing slope with $r^{2}$ of 0.80 , followed by petiole and fruit tissues with $r^{2}$ of 0.51 and 0.33 , respectively. This decrease may be due to the inhibition of the conversion of ACC to ethylene in the assay mixture by amines or other oxidizable compounds, as suggested by Nieder et al. (1986). Boiler et al. (1979) also found in a similar nonenzymatic assay that certain organic acids and sugar alcohols reduced the conversion efficiency of ACC to ethylene $>68 \%$.

In some tissues, ACC synthase is induced by auxin (Yoshii and Imaseki, 1982). If the induction of ethylene production in these tissues involves the de novo synthesis of ACC synthase, the cycling in temperature from warm days to cool nights likely would slow down the metabolism compared with a system such as described above where the tissue was kept at a constant temperature.

Results of this series of experiments suggest a close relationship between NAA-induced ethylene evolution from whole spurs in vivo and in excised spur tissues in vitro. Thus, this system of keeping excised spurs in vitro may well serve to study the effects of other abscission-inducing agents in more controlled environments. Martin and Brooks (1973) demonstrated a similar system, using leaf sections to screen for potential peach fruit thinning agents that resulted in a positive correlation between the rate of ethylene evolution in vitro and the amount of fruit thinning in the field.

Seasonal patterns of NAA-induced ethylene and ACC production indicate that leaf tissue is quite responsive to NAA shortly after bloom, decreasing to a minimum toward the end of July and increasing again slightly before harvest. Whole fruitlets responded little to NAA until the fruits matured in early October. Petiolar and cluster base tissue showed ethylene production rates similar to those of fruit tissue; however, concentrations of ACC were at times 10 times higher than in the fruit tissue. Thus, petiolar tissue may synthesize or transport ACC without as great a capacity for converting it to ethylene as leaf

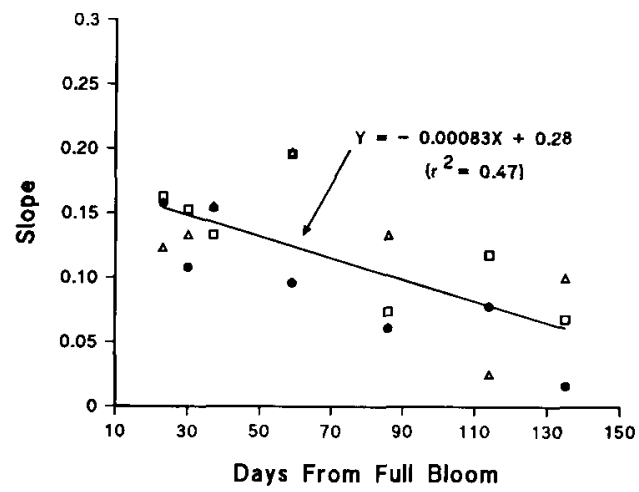

Fig. 6. Seasonal change in slope of standard addition assay of ACC from fruit $(\square)$, petiole cluster $(\triangle)$, and leaf $(O)$ tissue treated with $1000 \mathrm{mg}$ Regulaid/liter. Each data point represents the average slope of six tissue replications. 
tissue has. Interorgan transport of ACC has been shown by others (Bradford and Yang, 1980; Reid et al., 1984). This proposed transport suggests that the mode of action of NAA-induced fruitlet abscission maybe a result of ACC being synthesized in the leaf tissue and transported to the. site of abscission zone formation where it is converted to ethylene.

Others have shown that tissue sensitivity to plant growth substances may represent the limiting factor for activity rather than absolute concentration at the site of action (Bangerth, 1984; Trewavas, 1982). Clearly, apple spur tissues change in their ability to respond to NAA as the season progresses. After about "June drop," leaf tissue becomes unresponsive and remains in this state through harvest. These data do not answer the question of how NAA promotes fruit retention in the fall; however, they indicate that there is little stimulation of ethylene involved in the process at that time. Further efforts are needed to determine how NAA reduces preharvest fruit drop.

\section{Literature Cited}

Bangerth, F. 1984. Changes in sensitivity for ethylene during storage of apple and banana fruits under hypobaric conditions. Scientia Hort. 24:151-163.

Blanpied, G.D. 1972. A study of ethylene in apple, red raspberry and cherry. Plant Physiol. 49:627-630.

Boiler, T., R.C. Herner, and H. Kende. 1979. Assay and enzymatic formation of an ethylene precursor, l-aminocyclopropane-1 -carboxylic acid. Planta 145:293-303.

Bradford, K.J. and S.F. Yang. 1980. Xylem transport of 1-aminocyclopropane-1-carboxylic acid, an ethylene precursor, in waterlogged tomato plants. Plant Physiol. 65:322-326.

Burkholder, C.L. and M. McCown. 1941. Effect of scoring and of a naphthyl acetic acid and amide spray upon fruit set and of the spray upon preharvest fruit drop. Proc. Amer. Soc. Hort. Sci. 38:117120.

Crowe, A.D. 1965. Effect of thinning sprays on metabolism of growth substances in the apple. Proc. Amer. Soc. Hort. Sci. 86:23-37.

Ebert, A. and F. Bangerth. 1985. Veränderungen im Phytohormon- gehalt und mögliche Beziehungen zur Fruchtenwicklung beim Apfel. I. Extrahierbare IAA, GAs, ABA und Ethylen. Gartenbauwissenshaft 50:37-41.

Gardner, F. E., P.C. Marth, and L.P. Batjer. 1939. Spraying with plant growth substances for control of the preharvest drop of apples. Proc. Amer. Soc. Hort. Sci. 36:415-428.

Lizada, M.C.C. and S.F. Yang. 1979. A simple and sensitive assay for 1-aminocyclopropane-1-carboxylic acid. Anal. Biochem. 100:140145.

Lownds, N.K. and M.J. Bukovac. 1989. Surfactant-induced ethylene production by leaf tissue. J. Amer. Soc. Hort. Sci. 114:449-454.

Martin, G.C. and L.M. Brooks. 1973. A laboratory scale primary screening method for testing potential fruit thinning compounds. HortScience 8:498-499.

Neider, M., W.K. Yip, and S.F. Yang. 1986. Interferences and specificity of the 1-aminocyclopropane-1-carboxylic acid assay with the hypochlorite reagent. Plant Physiol. 81:156-160.

Reid, M. S., D.W. Fugino, N.E. Hoffman, and C.S. Whitehead. 1984. 1-aminocyclopropane-1-carboxylic acid (ACC) -The transmitted stimulus in pollinated flowers. J. Plant Growth Regulat. 3:189-196.

Schneider, G.W. 1975a. ${ }^{14} \mathrm{C}$-sucrose translocation in apple. J. Amer. Soc. Hort. Sci. 100:22-24.

Schneider, G.W. 1975b. Ethylene evolution and apple fruit thinning. J. Amer. Soc. Hort. Sci. 100:356-359.

Trewavas, A.J. 1982. Growth substance sensitivity: The limiting factor in plant development. Physiol. Plant. 55:60-72.

Walsh, C.S. and T. Solomos. 1987. Ethylene evolution by apple fruits during their early-season growth and development. Scientia Hort. 32:203-211.

Walsh, C. S., H.J. Swartz, and L.J. Edgerton. 1979. Ethylene evolution in apple following post-bloom thinning sprays. HortScience 14:704-706.

Weinbaum, S.A. and R.K. Simons. 1974. Histochemical appraisal of seed abortion to chemical induction of apple fruit abscission following bloom. J. Amer. Soc. Hort. Sci. 99:266-269.

Yoshii, H. and H. Imaseki. 1982. Regulation of auxin-induced ethylene biosynthesis. Repression of inductive formation of 1-aminocyclopropane-1-carboxylic synthase by ethylene. Plant Cell Physiol. 23:639-649. 